\title{
Developing a Framework for Mobile Learning Adoption and Sustainable Development
}

\author{
Sofia Moya $^{1}$ (D) Mar Camacho $^{1}$ (D)
}

Accepted: 10 June 2021

(c) The Author(s) 2021, corrected publication 2021

\begin{abstract}
Learning innovation for future education often includes digital approaches to enhance learning and to contribute to the development of twenty-first-century skills. There is evidence that mobile learning provides positive outcomes. However, there is a recognized lack of research in the field of frameworks and models that contributes to highlighting mobile learning rewards. This study aims to investigate the main characteristics of a strategic framework for the adaption and sustainable use of mobile learning. This study is based on a systematic review of 15 investigations published between 2009 and 2018. An adaptation of the strategic management framework by Jauch and Glueck (Business policy and strategic management, McGraw-Hill, London, 1988) was developed to show the results. The framework has a pedagogical foundation. Leaders, teachers, learners, families, and community members are identified as the key pillars upholding and maximizing mobile learning. The proposed framework is envisaged to serve as a guide for the educational community in implementing sustainable mobile learning.
\end{abstract}

Keywords Learning technology $\cdot$ Technology usage $\cdot$ Learning development $\cdot$ Learning processes $\cdot$ Change management

\section{Introduction}

Schools face the significant challenge of developing learning experiences to prepare students for the labour market, even though half of the jobs are expected to disappear in the future. Almost $40 \%$ of employers say a lack of skills is the main reason for entry-level vacancies (Mourshed et al. 2013). More than $60 \%$ of all jobs require a high level of critical thinking, creativity, and interpersonal skills (Horn 2014). Technological progress, infrastructure deployment, and falling prices have brought unexpected growth in ICT

Sofia Moya

Sofia.moya@urv.cat

Mar Camacho

mar.camacho@urv.cat

1 Department of Pedagogy, Universitat Rovira I Virgili, Campus Sescelades, Carretera de Valls, s/n, 43007 Tarragona, Spain 
(Information and Communication Technologies) access and connectivity to billions of people around the world.

A significant number of investigations have shown positive results in mobile learning. Wu et al. (2012) used a meta-analysis approach to systematically review 164 mobile learning studies published between 2003 and 2010, 86\% of the research results in the studies were significantly positive. Liu et al. (2014) reviewed 63 articles between 2007 and 2012 and found that $75 \%$ of the research results were positive. Crompton and Burke (2018) conducted a systematic review of the literature among 72 mobile learning studies and concluded that $70 \%$ showed positive results. The engagement with educational applications of mobile technologies has also risen in recent years (Islam and Grönlund 2016; Liaw et al. 2010; Pimmer 2016). Specifically, in the field of gamification, Connolly et al. (2012) conducted asystematic review of empirical evidence on computer games including 129 articles, and concluded that the most frequently occurring outcomes and impacts were knowledge acquisition/content understanding and affective and motivational outcomes.

Despite this relationship, there is a gap between the availability of technology and its use in the classroom; in addition, even when such use occurs, the results are often not optimized mainly because the technology's adoption neglects the fundamental elements of the process. The pedagogical use of powerful devices and digital resources has not yet been optimized (Alrasheedi and Capretz 2015; Cortese et al. 2015; Nikolopoulou and Gialamas 2016; Rikala 2015; Stevenson et al. 2015; Sutton and DeSantis 2017; Vahtivuori-Hänninen et al. 2012; Voogt et al. 2013). Until recently, mobile learning has primarily been used to facilitate the delivery of content rather than to change educational patterns (Miltenoff et al. 2013). Literature review has revealed a scarcity of theoretical frameworks for effective and sustainable mobile learning adoption (Alsaadat 2017; Ng and Nicholas 2013).

The main barriers identified when adopting mobile learning are related to technological resources; pedagogical factors; digital literacy; personal, character, attitudes and ethics; and leadership (Hamidi and Chavoshi 2018; Hao et al. 2017; Moya and Camacho 2020).

Sustainability is a key success factor for the successful adoption of mobile learning. Cisler (2002) developed a framework for sustainability in education based on four elements economic, social, political, and technological sustainability.

Although the matter of integrating technology into education in a strategic and sustainable manner is urgent, little research has been done in this regard. Most of the mobile learning literature has focused on effectiveness, the development of systems, influence characteristics, and the affective domain (Al-Zahrani and Laxman 2016; Crompton and Burke 2018; Fu and Hwang 2018; Hung and Zhang 2012; Krull and Duart 2017; Wu et al. 2012). Fundamentally, the target groups investigated have been comprised of students (Chee et al. 2018; Hwang and Tsai 2011; Mahdi 2018; Sung et al. 2016; Tingir et al. 2017). Therefore, there is a clear need to develop a solid, simple, and effective framework for the adoption and sustained use of mobile learning.

The objective of the current study is to facilitate the sustainable adoption of mobile learning by developing a solid, simple, and effective framework oriented to the main agents of the educational community. For this, a mobile learning framework has been developed based on elements of existing frameworks adapted to the strategic management framework proposed by Jauch and Glueck (1988). This study focuses on the following research questions: what are the main characteristics of a program for the adaption and sustained use of mobile learning? How these factors interrelate in an efficient and sustainable model, and what are the commonalities and differences from different existing mobile learning reports, and how they apply to the strategic framework developed by Jauch and Glueck (1988)? 


\section{Theoretical Background}

\subsection{Mobile Learning}

There are numerous definitions of mobile learning, and most of them highlight core characteristics such as mobility, ubiquity, interaction, and personalization (Cochrane 2010; Koole 2009; McDonald et al. 2018; Milrad et al. 2013; Peng et al. 2009). These characteristics enhance some of the fundamental learning principles published by the OECD and are based on both cognitive, emotional, and biological perspectives (Dumont et al. 2010), including placing learners at the center, the social nature of learning, emotions being integral to learning, recognizing individual differences, stretching all students, assessments for learning, and building horizontal connections (Grant 2019; Khaddage et al. 2016). Mobile learning strategies are fundamental to the constructivist learning perspective, which sees learning as a process of reconstruction rather than the transmission of knowledge (Papert and Harel 1991). The Program for International Student Assessment (PISA) revealed a strong correlation between the availability of technology in schools and students' performance in general (Ghamrawi 2013).

The literature has focused on several broad areas of inquiry, such as the effectiveness of mobile learning and the development of mobile learning systems to assist in student learning (Krull and Duart 2017; Wu et al. 2012). According to Krull and Duart (2017), based on their systematic review of 233 studies, the main purpose of studies was to evaluate effectiveness $24 \%$, followed by investigating system designs $23 \%$ and the affective domain $19 \%$, pursue developing theories $17 \%$, evaluate the affective domain $10 \%$ and evaluate the influence of learning 7\%. Comparatively, the number of studies focused on frameworks, models, and tools to implement mobile learning is significantly lower, and the need for further research is widely recognized (Armstrong et al. 2013; Cochrane 2010; Dalziel et al. 2016). Figure 1 shows this proportion based on publications published from 2008 to 2018 based on a Web of Science literature search. On average, only $7.8 \%$ of research focused on frameworks.

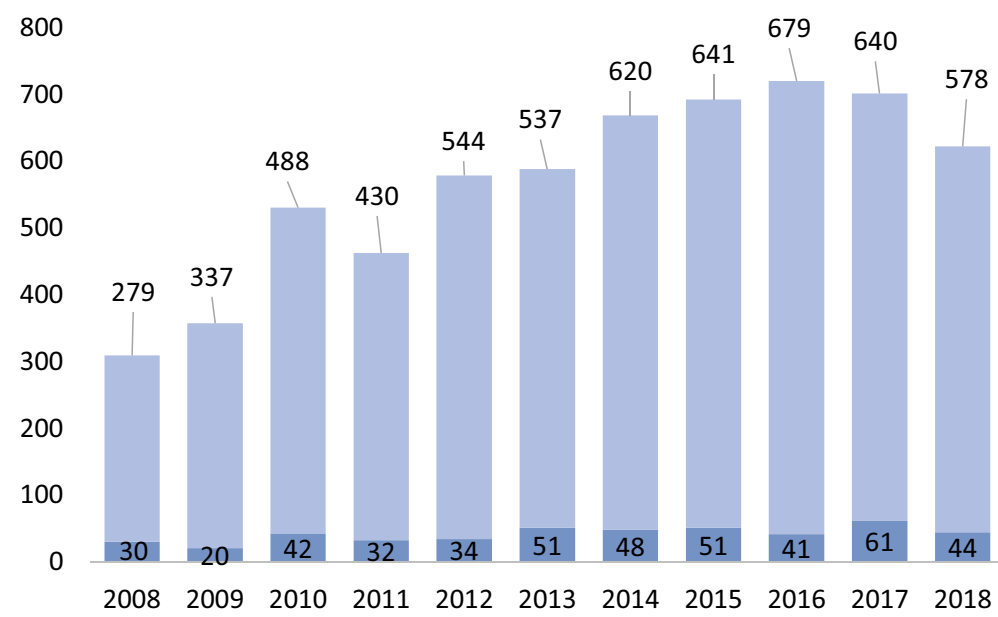

Fig. 1 Relationship between mobile learning studies dedicated to frameworks and the total literature published between 2009 and 2018 
The literature has proven successful in specifically formulating ICT frameworks, models, and strategies adaptable to mobile learning, such as the Substitution Augmentation Modification Redefinition (SAMR) model (Puentedura 2009); Technological Pedagogical Content Knowledge (TPACK) framework (Koehler and Mishra 2009); resource affordability and availability, such as Bring Your Own Device (BYOD); or space management, such as flipped classroom approaches (Camburn and Han 2015; Dalziel et al. 2016; Dobozy 2017; Penuel et al. 2011; Wiggins 2016; Williams and Larwin 2016).

\subsection{Strategic Management: Perspectives and Frameworks}

Educational management has successfully adopted countless management tools, particularly those oriented towards strategic management processes ( $\mathrm{Ng}$ and Nicholas 2013). Strategic planning is a vital instrument used in educational management to enhance its adaptability to its environment through innovative strategies and professional academic management (Hu et al. 2017). There is no universally accepted definition of strategic management; however, the most common approach concentrates on a strategic process perspective and considers strategic management as a sequence of strategically planned consecutive steps (Mintzberg and Quinn 2007; Porter 1996).

The literature is replete with coverage of and perspectives on strategic management; substantial issues are essentially the same across authors defining strategic management: establishing an organization's mission and setting strategic goals, scanning the external and internal environments, evaluating strategic options, developing a plan, allocating resources and monitoring results. Glueck (1984) developed a framework of strategic management based on the general decision-making process. For the purpose of this article, we will refer to the Glueck framework published jointly with Lawrence Jauch in 1988, for its clarity, precision, and simplicity (Fig. 2). Jauch and Glueck (1988) defined strategic management as a stream of decisions and actions that leads to the development of an effective strategy or strategies to help achieve corporate objectives.

- The first phase of the model refers to strategic management elements and is considered the core of strategic management. The management literature often defines the core elements as the vision, values, and mission of a firm (Gurley et al. 2015; Noble 1999).

- The second phase of the model refers to analysing the context. The most significant management models regarding the scanning environment phase are strengths, weaknesses, opportunities, and threats (SWOT) analysis (Jauch and Glueck 1988) and vulnerability, uncertainty, complexity, and ambiguity (VUCA) analysis (Bennett and Lemoine 2014).
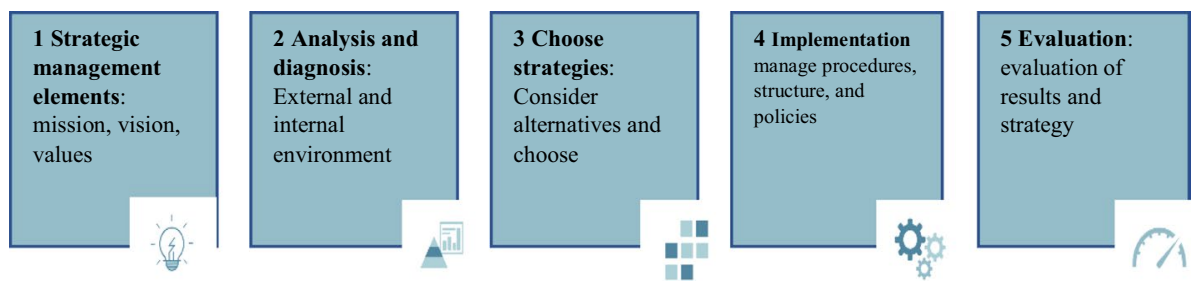

Fig. 2 Strategic management framework (Jauch and Glueck 1988) 
- The third phase of the model is to choose strategies, also called the strategy formulation or development phase, consisting of various alternatives and ensure that the appropriate strategy is chosen (Jauch and Glueck 1988).

- The fourth phase of the model refers to implementation, and it covers the challenge of matching plans, policies, resources, structures, and administrative styles with the strategy (Jauch and Glueck 1988; Noble 1999).

- The fifth and last phase of the model refers to evaluation.

In this context, the role of leaders is oriented towards guiding the process to match plans, policies, resources, structures, and administrative styles with the strategy (Jauch and Glueck 1988; Noble 1999).

\subsection{Strategic Management and Mobile Learning}

There has been considerable debate about the use of performance management tools in education. The literature shows that there are more examples demonstrating their value than there are detractors (Hernández-Ramos 2014; Ng and Nicholas 2013; Nikolopoulou and Gialamas 2016). The literature shows successful cases of management-based strategies that have been initiated in the business world and are widely integrated into educational environments. Strategies such as strategic planning, human resources management, space management, or specific technology strategies like BYOD, just to cite some (Camburn and Han 2015; Chen et al. 2014; Dalziel et al. 2016; Dobozy 2017; Ng and Nicholas 2013; Penuel et al. 2011; Peurach and Neumerski 2015; Williams and Larwin 2016).

\section{Methodology}

A systematic review (Hemingway and Brereton 2009) approach was performed in this study to answer the research question directing this study, with the goal of providing an impartial synthesis, a summary, and generalized relevant knowledge. To ensure that the review process was rigorous and valid, this study adapted the seven key steps identified in the practical guide to conducting and reporting systematic reviews created by Cook and West (2012), namely, (1) formulating the problem, (2) searching for eligible studies, (3) deciding on the inclusion and exclusion criteria, (4) abstracting key information, and (5) analysing the results.

\subsection{Problem Formulation}

Following the above-described process, the first phase was to formulate the problem (step 1); i.e., a literature review has revealed a scarcity of effective and holistic frameworks for the adoption of mobile learning. In this context, the purpose of this research was to understand the crucial characteristics of a strategic framework for the adaption and sustained use of mobile learning.

\subsection{Eligible Studies Search}

For the second phase of the systematic review process, the following methodology was followed (step 2): the literature search was concept-centric (Okoli and Schabram 2010). For 
literature reviews conducted in relation to education, the Web of Science database has been recommended by several previous studies (e.g., Fu and Hwang 2018). The expressions ("mobile learning" OR “ubiquitous learning" OR "blended learning” OR "M-learning" OR "B-learning” OR “mobile devices") AND ("framework" OR “model”) were used.

\subsection{Inclusion and Exclusion Criteria}

The third phase of the systematic review was to decide on the inclusion and exclusion criteria (steps 3 and 4); in this research, we used the following inclusion criteria:

1. The design of mobile learning frameworks or models was among the key variables of the study.

2. Mobile learning was oriented towards educational purposes.

3. The publication type was a journal article, book, or conference paper.

4. Internationally oriented publication venues were used.

Papers published before 2008 were excluded since previous studies eminently referred to instructional design (Krull and Duart 2017). Frameworks or models that focused exclusively on technical system design were also excluded. Grade levels and specific professional education programs were not excluded since the literature review shows that, for the most part, mobile learning frameworks are not specified in that regard. Of the 15 studies finally included in the systematic review, 10 did not specify a grade, one was oriented to primary education, two were oriented to secondary education, and two were oriented to higher education. The research process initially yielded 454 publications. However, by applying the second-listed inclusion criteria, the research was filtered by educational domain, and the search was narrowed to 104 studies. After excluding the studies dated more than 10 years ago, the number of studies was reduced to 32. Based on the article titles and keywords, 5 articles were excluded because they did not focus on mobile learning frameworks. A total of 27 full-text articles were screened by the two authors and based on the criteria, 15 articles were identified as eligible for the review and were thus comprehensively analysed by the authors (Table 1). Figure 3 shows the selection of the study process adapted from Yousra Banoor et al. (2019).

\subsection{Quality Assessment}

The criteria that were used to evaluate the quality of the publications are as follows:

1. They are based on academically relevant research methodologies.

2. They include a theoretical framework for the adoption of mobile learning with graphic representations.

3. Number of citations, increasingly considered a relevant indicator to evaluate the quality of research (Luo et al. 2018).

\subsection{Abstracting Information}

The fourth phase in the adapted systematic review process involved extracting key information (step 5) (Cook and West 2012). The data extraction was carried out based on the 
Table 1 Models and academic frameworks on mobile learning

\begin{tabular}{ll}
\hline Study & Framework/model \\
\hline Ada (2018) & Mobile learning framework for assessment feedback \\
Al-Hunaiyyan et al. (2017) & Cognitive knowledge-based framework for M-learning \\
Crompton (2017) & Mlearning integration framework \\
Hwang (2014) & Framework of a smart learning environment \\
Kearney et al. (2012) & Current framework comprising three distinctive characteristics of \\
& m-learning experiences, with sub-scales \\
Brummelhuis and van Amer- & The four in balance monitor \\
onge (2011) & The framework for the rational analysis of mobile education (FRAME) \\
Koole (2009) & Mlearning scaffolding five-stage model \\
Lim Abdullah et al. (2013) & Design framework for mobile learning \\
Liu et al. (2008) & Person-centred sustainable model for mobile learning \\
Ng and Nicholas (2013) & A framework for mobile learning design requirements for lifelong learning \\
Nordin et al. (2010) & Four types of mobile learning: a pedagogical framework \\
Park (2011) & The conceptual framework of ubiquitous knowledge construction \\
Peng et al. (2009) & Mobile learning framework \\
Rikala (2015) & The design and the role of different academic tools \\
Veerabhadram et al. (2012) &
\end{tabular}

different elements of the strategic framework by Jauch and Glueck (1988), with the following parameters: code, title, year, authors, citations, journal, name of the framework, grade level, vision/mission, environment analysis, strategies, implementation, evaluation, pedagogical methods, and stakeholders. The extracted information was synthesized and structured in a metadata table to facilitate analysis. Then, a thematic synthesis (Thomas et al. 2012) was conducted to analyse the principal elements.4 Research Results.

\subsection{Key information of the Studies}

Mobile learning models and frameworks integrate multiple and complex interrelated aspects and elements. To manage this complexity and facilitate organization, the strategic framework developed by Jauch and Glueck (1988) was used as a foundation (Fig. 2). Figure 4 describes the five phases of the framework adapted for mobile learning.

\subsection{Strategic Management Elements}

Multiple studies have defined mission, vision, and values as the core management elements (Gurley et al. 2015; Noble 1999). Table 2 shows the different approaches with which the studies included in this systematic review refer to the mission, vision, and values within their frameworks.

Synthesising the above references according to their mission and vision, the following understanding of the overall mission and vision was highlighted: enhancing mobile learning was the mission while gaining skills for the twenty-first century was the vision. Among all the studies, the following values were highlighted as crucial values for developing a solid mobile learning framework: collaboration, communication, creativity, trust, and culture. These values 


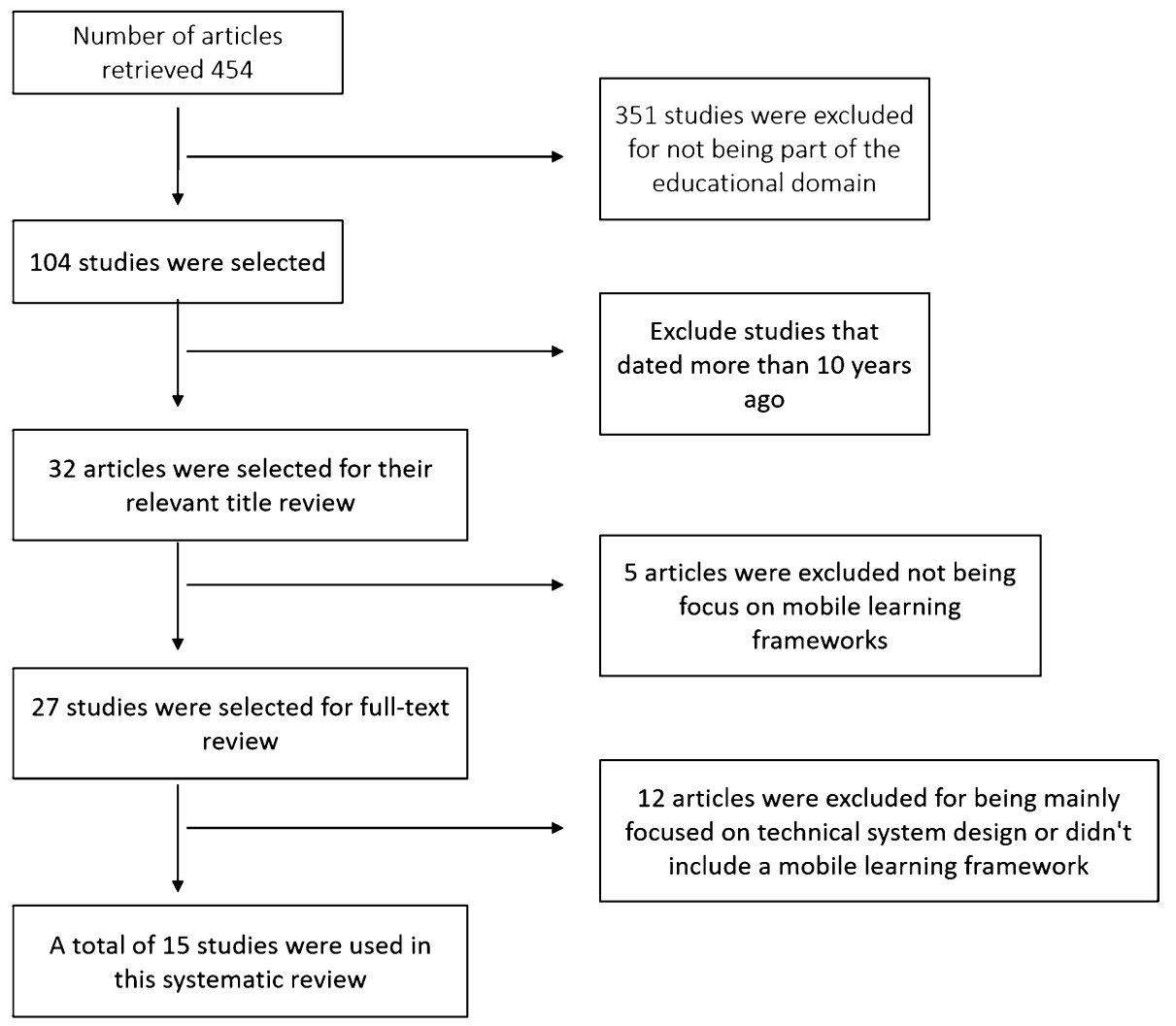

Fig. 3 Selection of studies process ( adapted from Yousra Banoor et al. 2019)

comprise the frame of reference that guides decision-making at all times. To provide further details about the framework, a strategy tool has been designed. The top of Fig. 5 shows the first phase of the framework for the sustainable adoption and development of mobile learning.

\subsection{Analysis and Diagnosis}

The second phase of Jauch and Glueck's framework focuses on the external environment and internal analysis and diagnosis. Different approaches to the environment have been detected in the different studies analyzed and are shown in Table 3.

The right side of Fig. 5 shows the second phase of the framework. An external environmental analysis indicates the global levels of the development of resources (human, pedagogical and technological) and an internal analysis refers to the internal availability of resources.

\subsection{Strategic Choices}

The third phase of Jauch and Glueck's model examines strategic choices and formulations. All the models and frameworks analysed used a combination of different pedagogical and technological strategies as the key strategies of their mobile learning 


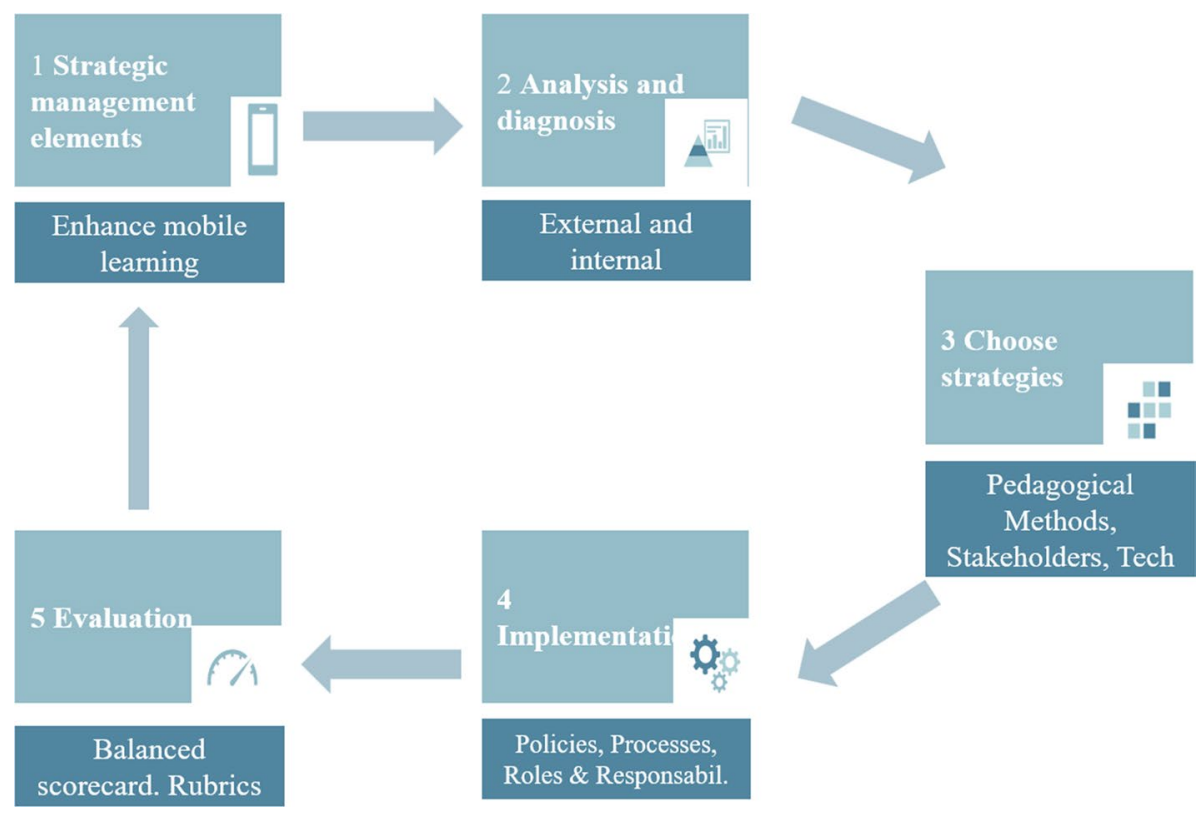

Fig. 4 Strategic management framework (Jauch and Glueck 1988) adapted for mobile learning adoption

Table 2 References to mission, vision, and values in mobile learning frameworks

\begin{tabular}{|c|c|}
\hline References to mission, vision, and values & Studies \\
\hline $\begin{array}{l}\text { Learning objectives, learning outcomes, and learning } \\
\text { progress }\end{array}$ & $\begin{array}{l}\text { Lim Abdullah et al. (2013), Nordin et al. (2010) and } \\
\text { Rikala (2015) }\end{array}$ \\
\hline Vision as ubiquitous knowledge construction & Brummelhuis and van Amerongen (2011) \\
\hline $\begin{array}{l}\text { Vision as ubiquitous knowledge construction and } \\
\text { values }\end{array}$ & Peng et al. (2009) \\
\hline $\begin{array}{l}\text { Values (communication, collaboration, and culture) } \\
\text { and learning objectives, learning outcomes, and } \\
\text { learning progress }\end{array}$ & Ada (2018) \\
\hline $\begin{array}{l}\text { Values (culture, standards, collaboration; creativity) } \\
\text { and purpose of the study }\end{array}$ & $\begin{array}{l}\text { Crompton (2017), Hwang (2014), Liu et al. (2008) } \\
\text { and Park (2011) }\end{array}$ \\
\hline
\end{tabular}

frameworks or models. Table 4 depicts the categorization into one of these two strategic categories of each framework or model.

Pedagogical strategies include theories of learning (constructivism, behaviourism, and conceptualism, among others); general approaches, theories, and tools (such as mobile application, multimedia design theory, content applications, activity design) and pedagogical approaches (collaboration, personalization, authenticity). Technological strategies refer to resource characteristics (device, tools, materials, banks of digital resources) and technological support. The third row of Fig. 5 shows the third phase of the framework. 


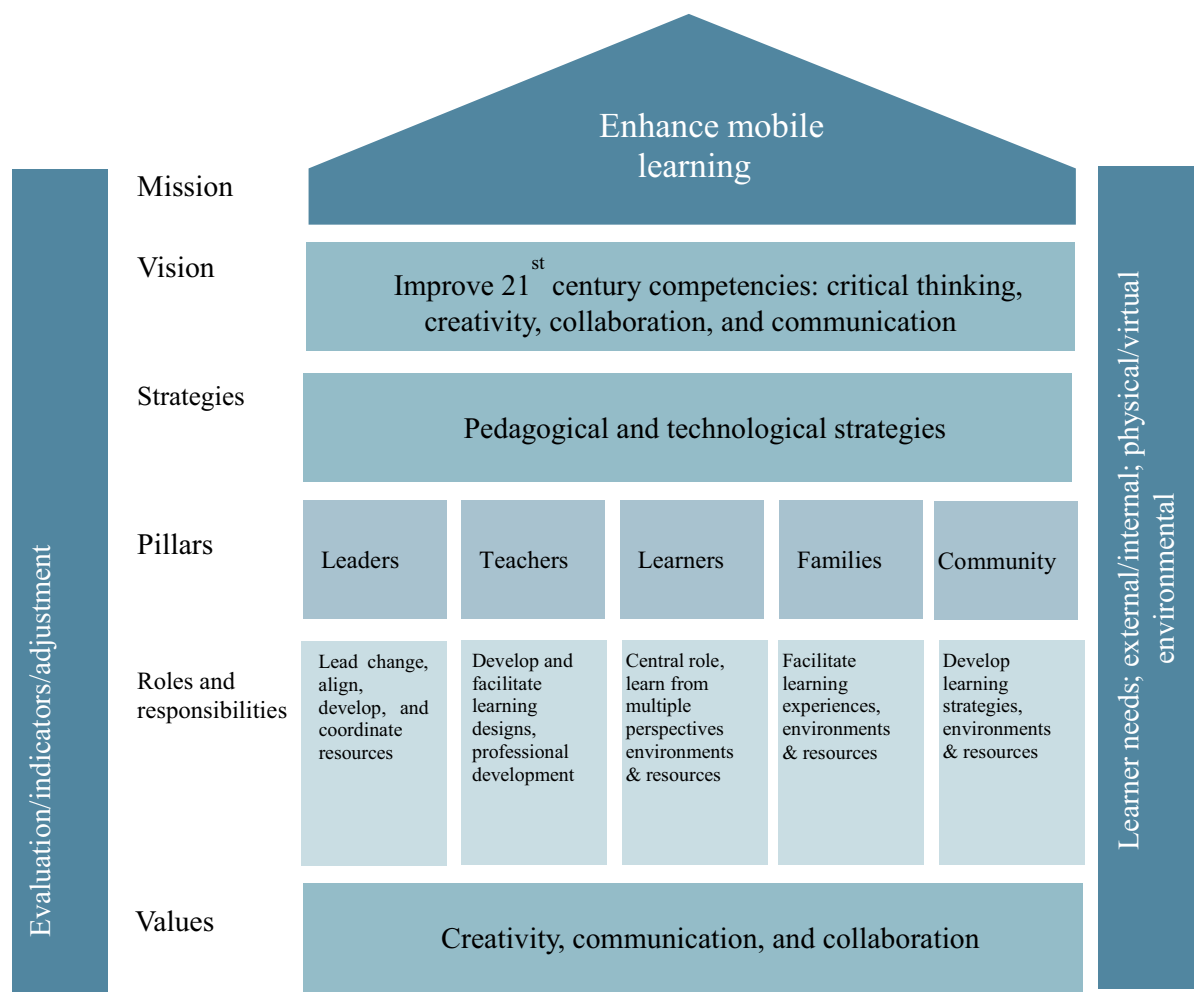

Fig. 5 Mobile learning strategic management framework

Table 3 References to the environment in mobile learning frameworks

\begin{tabular}{|c|c|}
\hline Reverences to environment & Studies \\
\hline Contextualization & $\begin{array}{l}\text { Brummelhuis and van Amerongen (2011), Kearney } \\
\text { et al. (2012), Koole (2009), Lim Abdullah et al. } \\
\text { (2013), Liu et al. (2008), Nordin et al. (2010) and } \\
\text { Park (2011) }\end{array}$ \\
\hline Learning environment & Hwang (2014) \\
\hline $\begin{array}{l}\text { Context three areas: curriculum, ICT strategies, and } \\
\text { teacher competencies }\end{array}$ & Rikala (2015) \\
\hline $\begin{array}{l}\text { Suppliers, software developers, government bodies, } \\
\text { the media, and researchers }\end{array}$ & $\mathrm{Ng}$ and Nicholas (2013) \\
\hline
\end{tabular}

\subsection{Implementation}

The fourth phase of Jauch and Glueck's model focuses on implementation. Stakeholders are considered the key pillars for mobile learning adoption, not only during the implementation phase but also throughout the process. Table 5 shows the stakeholders on which the frameworks included in this analysis were based. 


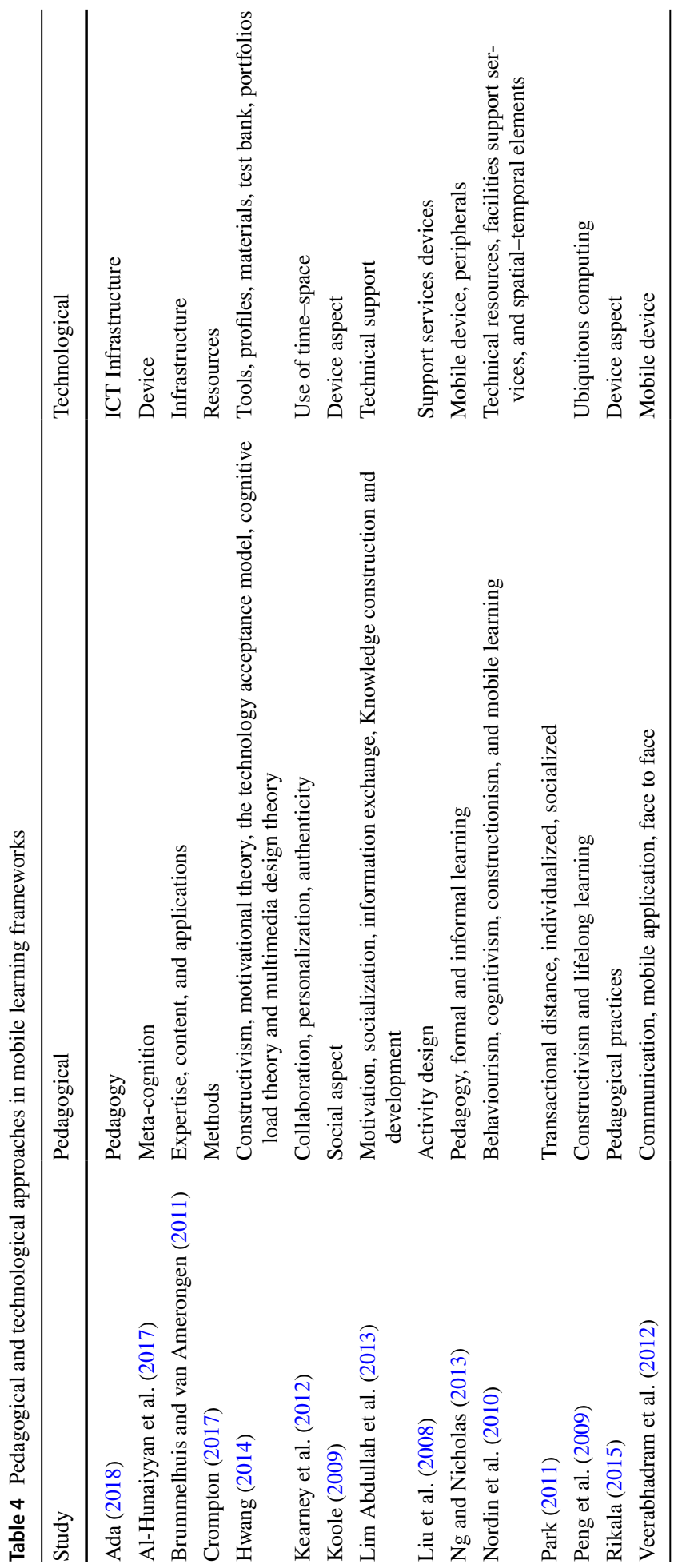


To present the framework, the key stakeholders were identified as leaders, teachers, learners, families, and community members. These key pillars have been considered independently; however, they constantly interact with each other. The roles and responsibilities of each of the pillars depend on their mobile learning impact. Islam and Grönlund (2016) conducted a review of 145 papers from 2000 to 2012 to accumulate evidence of the uses and impacts of computer learning. Most of the literature reviewed by the authors was focused on the articles by Fisher (2005-2010), Holcomb (2003-2008) and, Penuel (2001-2005). Table 6 shows the results that Islam and Grönlund adapted for each of the framework pillars.

The leader's category includes principals, heads of schools/faculties, school managers, administrators, and coordinators of programs. Leaders are responsible for constantly guiding the school in response to new cultural challenges, environmental demands, resources, and expectations. Ng and Nicholas (2013) outlined that leadership and management roles are focused on deciding policies, managing finances, and providing leadership support. Figure 5 shows the crucial roles for leaders, i.e., lead changes and align, develop, and coordinate resources.

The main role for teachers has switched from class leader to facilitator (Ada 2018; Hwang and Wu 2014; $\mathrm{Ng}$ and Nicholas 2013). Teachers are responsible for both developing learning designs and their own professional development. Learning design is oriented towards developing pedagogical methodologies that optimize resources. As mentioned in the literature review, some of the educational strategies and models such as SAMR, TPACK, BYOD and, flipped classroom are adaptable to mobile learning (Koole 2009; Ng and Nicholas 2013; Rikala 2014). Figure 5 reflects the key responsibilities of teachers, i.e., develop and facilitate both learning designs and professional development.

The learner's role has moved to the centre of the learning process (Hwang 2014; $\mathrm{Ng}$ and Nicholas 2013; Veerabhadram et al. 2012). Thus, learners must broaden their responsibilities to include a proactive contribution to the mobile learning process. Student-centred designs are rooted in constructivist and constructionist pedagogical theories and seek to develop learner autonomy and independence (Hwang 2014). Figure 5 outlines the learnercentred role and responsibilities, i.e., maintain a central role and learn from multiple perspectives, environments, and resources.

The category of families refers to the people from the close environment of the learner, who facilitate and participate in the student's learning process. In their framework, $\mathrm{Ng}$ and

Table 5 Stakeholders identified in mobile learning frameworks

\begin{tabular}{|c|c|}
\hline References to stakeholders & Studies \\
\hline Educator & Crompton (2017) \\
\hline Learner & $\begin{array}{l}\text { Ada (2018), Al-Hunaiyyan et al. (2017), Hwang } \\
\text { (2014), Kearney et al. (2012), Koole (2009), Lim } \\
\text { Abdullah et al. (2013), Nordin et al. (2010), Park } \\
\text { (2011), Peng et al. (2009) and Rikala (2015) }\end{array}$ \\
\hline Learner, organization, project team, community & Liu et al. (2008) \\
\hline Student and lecturer & Veerabhadram et al. (2012) \\
\hline $\begin{array}{l}\text { Teachers; school managers and administrators, } \\
\text { parents, support staff and learners }\end{array}$ & Brummelhuis and van Amerongen (2011) \\
\hline $\begin{array}{l}\text { Technician, students, teachers, parents, leaders and } \\
\text { managers, wider community }\end{array}$ & Ng and Nicholas (2013) \\
\hline
\end{tabular}


Table 6 Mobile learning impact on stakeholders

\begin{tabular}{ll}
\hline Key pillar & Mobile learning impact \\
\hline Leaders & Access to in the class content \\
Improve multilevel communication \\
Standardization to ensure quality levels \\
Team management motivation \\
Online feedback \\
Classroom dynamism \\
Collaboration \\
Computing skills \\
Constructivist and flexible teaching \\
Discipline behaviour problems \\
Teacher-student interaction improve \\
Professional development \\
Overdependency on information (negative) \\
Cognitive skills \\
Computing skills \\
Engagement and motivation \\
Help special needs students \\
Homework \\
Quality of work and achievements \\
Research and writing skills \\
Self-direct, independent learning \\
Insignificant academic achievement (negative) \\
Physiological as well as physical strains (negative) \\
Additional distraction (negative) \\
Increases parental involvement in school and technological literacy \\
Assist homework \\
Industry: increases innovations and sales; reduce prices \\
Reduce socio-educational inequalities \\
\hline \\
Community & \\
& \\
&
\end{tabular}

Adaptation from Islam and Grünlund (2016)

Nicholas (2013) grouped parent responsibilities according to their relationship with other stakeholders: communicate and provide support and trust to students; negotiate costs with, consult with, inform, and provide feedback to leaders; and consult and provide feedback to teachers.. Figure 5 summarizes the fundamental responsibilities of families, i.e., facilitate learning experiences, environments, and resources.

Isler's framework for the sustainability of ICT in education, cited by $\mathrm{Ng}$ and Nicholas (2013), highlighted the role of the community as the potential link to economic, social, and political aspects of sustainability. The community pillar is not limited to educational institutions and policymakers but also includes a wide range of organizations, such as technology developers, business partners (e.g., computer companies), educational consultants, researchers, and political leaders. Consequently, community members' contribution to the framework covers a wide range of endeavours, including developing new learning environments and resources to ensure the sustainability of the framework. According to $\mathrm{Ng}$ and Nicholas (2013), this sustainability has five main dimensions: economic, social, 
technological, political, and pedagogical. The fourth and fifth rows of Fig. 5 show the responsibilities of pillars and community members, i.e., develop learning strategies, environments, and resources.

\subsection{Evaluation}

The fifth and last phase of Jauch and Glueck's model is the evaluation phase. Evaluation is a crucial phase in strategic planning since it allows evaluators to readjust and focus on the process. Four studies included evaluation or assessment in their frameworks (Hwang 2014; $\mathrm{Ng}$ and Nicholas 2013; Rikala 2015; Veerabhadram et al. 2012). All the frameworks considered the evaluation part of the learning design or pedagogical activity oriented towards monitoring and evaluating learning progress and outcomes. The left part of Fig. 5 shows the fifth phase of the model. In total, Fig. 5shows the complete framework for the adoption and sustainable development of mobile learning.

\section{Discussion and Conclusion}

The purpose of this study was to identify the main characteristics of a strategic management framework for the adoption and sustained use of mobile learning. The main contribution of this work is the presentation of a mobile learning framework adapted from the strategic management proposed by Jauch and Glueck (1988), based on elements of existing frameworks. A framework that orchestrates in a holistic way the results of the main studies that have proposed frameworks for the adoption of mobile learning during the last 10 years. The framework is presented in Fig. 5 and is comprised of five main strategic management phases: strategic elements; context analysis; strategic choices; implementation; and evaluation. While these five phases are listed separately, it is important to note that they are highly interconnected. Despite the relevance of the evaluation phase (Ada 2018), few frameworks considered evaluation as part of the learning design or pedagogical activity aimed at monitoring and evaluating learning progress and outcomes. Leaders, teachers, learners, families, and community members have been identified as the key pillars who uphold and maximize mobile learning strategies. Given the complex and dynamic nature of implementation situations, it really can be difficult to achieve and maintain coherence between the different pillars, however, is crucial. Only two of the frameworks analyzed (Brummelhuis and van Amerongen 2011; Ng and Nicholas 2013) include roles and responsibilities for all members of the educational community. The proposed framework is envisaged to serve as a guide for the educational community regarding implementing sustainable mobile learning.

One of the major contributions of this framework is that it considers the main barriers identified in the adoption of mobile learning: related to technological resources; pedagogical factors; digital literacy; personality, character, attitudes, and ethics; and leadership. It also provides a coherent model for all members of the educational community oriented to the adoption of mobile learning in a practical and effective way. The framework includes evaluation as a fundamental element of the fundamental learning principles highlighted by current research. Finally, it ensures the solidity of the five elements on which sustainability in education is based: economic, social, political, technological, and pedagogical.

The main limitation of this study is that the framework has not been tested. The framework developed in this study can be empirically tested and improved by investigating 
cases of mobile learning implementation. The framework has not been designed for a specific educational context; it is also important to note that cultural bias may occur. Thus, additional research is needed to verify in what specific scenarios the framework could be adopted. This need requires the study of more in-depth perspectives of the framework. Going forward, it would be beneficial for researchers to study the framework in various educational contexts to see if there is anything that has been omitted from the mobile learning integration framework that needs to be added. The current findings are likely to change with ongoing technological developments. The framework also identifies interactions that could be studied in the future.

Funding Open Access funding provided thanks to the CRUE-CSIC agreement with Springer Nature. This research did not receive any specific grant from funding agencies in the public, commercial, or not-for-profit sectors.

Open Access This article is licensed under a Creative Commons Attribution 4.0 International License, which permits use, sharing, adaptation, distribution and reproduction in any medium or format, as long as you give appropriate credit to the original author(s) and the source, provide a link to the Creative Commons licence, and indicate if changes were made. The images or other third party material in this article are included in the article's Creative Commons licence, unless indicated otherwise in a credit line to the material. If material is not included in the article's Creative Commons licence and your intended use is not permitted by statutory regulation or exceeds the permitted use, you will need to obtain permission directly from the copyright holder. To view a copy of this licence, visit http://creativecommons.org/licenses/by/4.0/.

\section{References}

Ada, M. (2018). Using design-based research to develop a mobile learning framework for assessment feedback. Research and Practice in Technology Enhanced Learning, 13(1), 3. https://doi.org/10.1186/ s41039-018-0070-3.

Al-Hunaiyyan, A., Bimba, A. T., Idris, N., \& Al-Sharhan, S. (2017). A cognitive knowledge-based framework for social and metacognitive support in mobile learning. Interdisciplinary Journal of Information Knowledge and Management, 12075-12098. https://doi.org/10.28945/3670.

Alrasheedi, M., \& Capretz, L. F. (2015). Determination of critical success factors affecting mobile learning: A meta-analysis approach. The Turkish Online Journal of Educational Tec, 14(2), 41.

Alsaadat, K. (2017). Mobile learning-An alternative approach in higher education. European Journal of Alternative Education Studies. https://doi.org/10.5281/zenodo.815474

Al-Zahrani, H., \& Laxman, K. (2016). A critical meta-analysis of mobile learning research in higher education. The Journal of Technology Studies. https://doi.org/10.21061/jots.v41i2.a.1

Armstrong, A. W., Harskamp, C. T., \& Armstrong, E. J. (2013). Psoriasis and the risk of diabetes mellitus: A systematic review and meta-analysis. JAMA Dermatology, 149(1), 84-91.

Bennett, N., \& Lemoine, J. (2014). What VUCA really means for you. Harward Business Review, 92(1/2), $14-18$.

Brummelhuis, A., \& van Amerongen, M. (2011). Four in Balance Monitor 2011. ICT in Dutch primary, secondary and vocational education.

Camburn, E. M., \& Han, S. W. (2015). Infrastructure for teacher reflection and instructional change: An exploratory study. Journal of Educational Change, 16(4), 511-533. https://doi.org/10.1007/ s10833-015-9252-6

Chee, K. N., Yahaya, N., \& Ibrahim, N. H. (2018). Factors of students' performance based on cognitive level in a mobile learning environment. International Journal of Mobile Learning and Organisation, 12(2), 190-212.

Chen, C. P., Shih, J. L., \& Ma, Y. C. (2014). Using instructional pervasive game for school children's cultural learning. Journal of Educational Technology and Society, 17(2), 169-182.

Cisler, S. (2002). Schools on line planning for sustainability: How to keep your ICT project running. 
Cochrane, T. (2010). Exploring mobile learning success factors. ALT-J, 18(2), 133-148. https://doi.org/10. 1080/09687769.2010.494718

Connolly, T., Boyle, E., MacArthur, E., Hainey, T., \& Boyle, J. (2012). A systematic literature review of empirical evidence on computer games and serious games. Computers and Education, 59(2), 661-686.

Cook, D. A., \& West, C. P. (2012). Conducting systematic reviews in medical education: A stepwise approach. Medical Education, 46(10), 943-952. https://doi.org/10.1111/j.1365-2923.2012.04328.x

Cortese, S., Ferrin, M., Brandeis, D., Buitelaar, J., Daley, D., Dittmann, R. W., Holtmann, M., Santosh, P., Stevenson, J., \& Stringaris, A. (2015). Cognitive training for attention-deficit/hyperactivity disorder: Meta-analysis of clinical and neuropsychological outcomes from randomized controlled trials. Journal of the American Academy of Child and Adolescent Psychiatry, 54(3), 164-174.

Crompton, H. (2017). Moving toward a mobile learning landscape: Presenting a mlearning integration framework. Interactive Technology and Smart Education, 14(2), 97-109. https://doi.org/10.1108/ ITSE-02-2017-0018.

Crompton, H., \& Burke, D. (2018). The use of mobile learning in higher education: A systematic review. Computers and Education, 123, 53-64. https://doi.org/10.1016/j.compedu.2018.04.007

Dalziel, J., Conole, G., Wills, S., Walker, S., Bennett, S., Dobozy, E., Cameron, L., Badilescu-Buga, E., \& Bower, M. (2016). The larnaca declaration on learning design. Journal of Interactive Media in Education. https://doi.org/10.5334/jime.407

Dobozy, E. (2017). The pre-designed lesson: Teaching with transdisciplinary pedagogical templates (Tpts). Technology, Knowledge and Learning, 22(2), 143-150. https://doi.org/10.1007/s10758-017-9304-5

Dumont, H., Istance, D., \& Benavides, F. (2010). The nature of learning: Using research to inspire practice. https://doi.org/10.1787/9789264086487.

Fu, Q., \& Hwang, G. (2018). Trends in mobile technology-supported collaborative learning: A systematic review of journal publications from 2007 to 2016. Computers and Education, 119, 129-143. https:// doi.org/10.1016/j.compedu.2018.01.004

Ghamrawi, N. (2013). In principle, it is not only the principal! Teacher leadership architecture in schools. International Education Studies, 6(2), 148-159.

Grant, M. M. (2019). Difficulties in defining mobile learning: Analysis, design characteristics, and implications. Educational Technology Research and Development, 67(2), 361-388. https://doi.org/10.1007/ s11423-018-09641-4

Gurley, D. K., Peters, G. B., Collins, L., \& Fifolt, M. (2015). Mission, vision, values, and goals: An exploration of key organizational statements and daily practice in schools. Journal of Educational Change, 16(2), 217-242. https://doi.org/10.1007/s10833-014-9229-x

Hamidi, H., \& Chavoshi, A. (2018). Analysis of the essential factors for the adoption of mobile learning in higher education: A case study of students of the University of Technology. Telematics and Informatics, 35(4), 1053-1070.

Hao, S., Dennen, V. P., \& Mei, L. (2017). Influential factors for mobile learning acceptance among Chinese users. Educational Technology Research and Development, 65(1), 101-123.

Hemingway, P., \& Brereton, N. (2009). What is a systematic review. In What is series (pp.1-8).

Hernández-Ramos, J. (2014). Teachers' attitude regarding the use of ICT. A factor reliability and validity study. Computers in Human Behavior, 31, 509-516.

Horn, C. (2014). The young scholars model. In Effective program models for gifted students from underserved populations (pp. 45-60).

Hu, J., Liu, H., Chen, Y., \& Qin, J. (2017). Strategic planning and the stratification of Chinese higher education institutions. International Journal of Educational Development. https://doi.org/10.1016/j.ijedudev. 2017.03.003

Hung, J.-L., \& Zhang, K. (2012). Examining mobile learning trends 2003-2008: A categorical meta-trend analysis using text mining techniques. Journal of Computing in Higher Education, 24(1), 1-17. https:// doi.org/10.1007/s12528-011-9044-9

Hwang, G.-J. (2014). Definition, framework and research issues of smart learning environments-A context-aware ubiquitous learning perspective. Smart Learning Environments, 1(1), 4. https://doi.org/10. 1186/s40561-014-0004-5

Hwang, G.-J., \& Tsai, C.-C. (2011). Research trends in mobile and ubiquitous learning: A review of publications in selected journals from 2001 to 2010: Colloquium. British Journal of Educational Technology, 42(4), E65-E70. https://doi.org/10.1111/j.1467-8535.2011.01183.x

Hwang, G.-J., \& Wu, P.-H. (2014). Applications, impacts and trends of mobile technology-enhanced learning: A review of 2008-2012 publications in selected SSCI journals. International Journal of Mobile Learning and Organisation, 8(2), 83-95. https://doi.org/10.1504/ijmlo.2014.062346

Islam, M. S., \& Grönlund, A. (2016). An international literature review of 1: 1 computing in schools. Journal of Educational Change, 17(2), 191-222. https://doi.org/10.1007/s10833-016-9271-y 
Jauch, L. R., \& Glueck, W. F. (1984). Business policy and strategic management. New York: McGraw-Hill. Jauch, L. R., \& Glueck, W. F. (1988). Business policy and strategic management. London: McGraw-Hill.

Kearney, M., Schuck, S., Burden, K., \& Aubusson, P. (2012). Viewing mobile learning from a pedagogical perspective. In Research in Learning Technology, 20(1).

Khaddage, F., Müller, W., \& Flintoff, K. (2016). Advancing mobile learning in formal and informal settings via mobile app technology: Where to from here, and how? Journal of Educational Technology and Society, 19(3), 16-26.

Koehler, M., \& Mishra, P. (2009). What is technological pedagogical content knowledge (TPACK)? Contemporary Issues in Technology and Teacher Education, 9(1), 60-70.

Koole, M. (2009). A model for framing mobile learning. In M. Ally (Ed.), Mobile learning: Transforming the delivery of education and training (pp. 25-47). Athabasca: AU Press.

Krull, G., \& Duart, J. M. (2017). Research trends in mobile learning in higher education: A systematic review of articles (2011 - 2015). International Review of Research in Open and Distance Learning, 18(7), 1-23. https://doi.org/10.19173/irrodl.v18i7.2893

Liaw, S.-S., Hatala, M., \& Huang, H.-M. (2010). Investigating acceptance toward mobile learning to assist individual knowledge management: Based on activity theory approach. Computers and Education, 54(2), 446-454. https://doi.org/10.1016/j.compedu.2009.08.029

Lim Abdullah, M. R. T., Hussin, Z., Asra, B., \& Zakaria, A. R. (2013). MLearning scaffolding model for undergraduate English language learning: Bridging formal and informal learning. TOJET: The Turkish Online Journal of Educational Technology, 12(2), 217-233.

Liu, H., Huang, R., Salomaa, J., \& Ma, D. (2008). An activity-oriented design framework for mobile learning experience. Fifth IEEE International Conference on Wireless, Mobile, and Ubiquitous Technology in Education, 185-187. https://doi.org/10.1109/WMUTE.2008.30.

Liu, M., Scordino, R., Geurtz, R., Navarrete, C., Ko, Y., Lim, M. (2014). A look at research on mobile learning in K-12 education from 2007 to the present. Journal of Research on Technology in Education, 46(4), 325-372. https://doi.org/10.1080/15391523.2014.925681.

Luo, F., Sun, A., Erdt, M., Sesagiri Raamkumar, A., \& Theng, Y.-L. (2018). Exploring prestigious citations sourced from top universities in bibliometrics and altmetrics: A case study in the computer science discipline. Scientometrics, 114(1), 1-17. https://doi.org/10.1007/s11192-017-2571-z

Mahdi, H. S. (2018). Effectiveness of mobile devices on vocabulary learning: A meta-analysis. Journal of Educational Computing Research, 56(1), 134-154. https://doi.org/10.1177/0735633117698826

McDonald, E. W., Boulton, J. L., \& Davis, J. L. (2018). E-learning and nursing assessment skills and knowledge-An integrative review. Nurse Education Today, 66, 166-174. https://doi.org/10.1016/j. nedt.2018.03.011

Milrad, M., Wong, L., Sharples, M., Hwang, G., Looi, C., \& Otawa, H. (2013). Seamless learning: An international perspective on next-generation technology-enhanced learning. In Z. L. Berge \& L. Muilenburg (Eds.), Handbook of mobile learning (pp. 95-108). London: Routledge. https://doi.org/ $10.4324 / 9780203118764$

Miltenoff, P., Keengwe, J., \& Schnellert, G. (2013). Technological strategic planning and globalization in higher education. In L. A. Tomei (Ed.), Learning tools and teaching approaches through ICT advancements (pp. 348-358). New York: IGI Global. https://doi.org/10.4018/978-1-4666-2017-9. ch030

Mintzberg, H., \& Quinn, B. (2007). Planeación estratégica. España: Ediciones Díaz de Santos.

Mourshed, M., Farrell, D., \& Barton, D. (2013). Education to employment: Designing a system that works. New York: McKinsey Center for Government.

Moya, S., \& Camacho, M. (2020). Identifying the key success factors for the adoption of mobile learning. Education and Information Technologies, 25(1), 1-29. https://doi.org/10.1007/s10639-021-10447-w

Ng, W., \& Nicholas, H. (2013). A framework for sustainable mobile learning in schools. British Journal of Educational Technology, 44(5), 695-715. https://doi.org/10.1111/j.1467-8535.2012.01359.x

Nikolopoulou, K., \& Gialamas, V. (2016). Barriers to ICT use in high schools: Greek teachers' perceptions. Journal of Computers in Education, 3(1), 59-75. https://doi.org/10.1007/s4069

Noble, C. H. (1999). Building the strategy implementation network. Business Horizons, 42(6), 19.

Nordin, N., Embi, M. A., \& Yunus, M. M. (2010). Mobile learning framework for lifelong learning. Procedia - Social and Behavioral Sciences, 7, 130-138. https://doi.org/10.1016/j.sbspro.2010.10.019.

Okoli, C., \& Schabram, K. (2010). A guide to conducting a systematic literature review of information systems research. SSRN Electronic Journal. https://doi.org/10.2139/ssrn.1954824

Park, Y. (2011). A pedagogical framework for mobile learning: Categorizing educational applications of mobile technologies into four types. The International Review of Research in Open and Distributed Learning, 12(2), 78. https://doi.org/10.19173/irrodl.v12i2.791.

Papert, S., \& Harel, I. (1991). Situating constructionism. Constructionism, 36(2), 1-11. 
Peng, H., Su, Y., Chou, C., \& Tsai, C.-C. (2009). Ubiquitous knowledge construction: Mobile learning re-defined and a conceptual framework. Innovations in Education and Teaching International, 46(2), 171-183. https://doi.org/10.1080/14703290902843828

Penuel, W. R., Fishman, B. J., Haugan Cheng, B., \& Sabelli, N. (2011). Organizing research and development at the intersection of learning, implementation, and design. Educational Researcher, 40(7), 331-337. https://doi.org/10.3102/0013189X11421826

Peurach, D. J., \& Neumerski, C. M. (2015). Mixing metaphors: Building infrastructure for large scale school turnaround. Journal of Educational Change, 16(4), 379-420. https://doi.org/10.1007/ s10833-015-9259-z

Pimmer, C. (2016). Mobile learning as boundary crossing: An alternative route to technology-enhanced learning? In Interactive learning environments, 24(5), 979-990.

Porter, M. E. (1996). What is strategy. Harvard Business Review, November-D.

Puentedura, R. (2009). As we may teach: Educational technology, from theory into practice. /Itunes. Apple. Com/Itunes-u/as-Wemay-Teach-Educational/Id380294705.

Rikala, J. (2014). Evaluating QR code case studies using a mobile learning framework. https://eric.ed. gov/?id=ED557210.

Rikala, J. (2015). Designing a mobile learning framework for a formal educational context. In Jyväskylä studies in computing. Jyväskylän studies in computing.

Stevenson, M., Hedberg, J. G., O’Sullivan, K.-A., \& Howe, C. (2015). Development to learning: Semantic shifts in professional autonomy and school leadership. Educational Media International, 52(3), 173187. https://doi.org/10.1080/09523987.2015.1075100

Sung, Y. T., Chang, K. E., \& Liu, T. C. (2016). The effects of integrating mobile devices with teaching and learning on students' learning performance: A meta-analysis and research synthesis. Computers and Education, 94, 252-275. https://doi.org/10.1016/j.compedu.2015.11.008

Sutton, K. K., \& DeSantis, J. (2017). Beyond change blindness: Embracing the technology revolution in higher education. Innovations in Education and Teaching International, 54(3), 223-228. https://doi. org/10.1080/14703297.2016.1174592

Thomas, J., Harden, A., \& Newman, M. (2012). Synthesis: Combining results systematically and appropriately. London: Sage.

Tingir, S., Cavlazoglu, B., Caliskan, O., Koklu, O., \& Intepe-Tingir, S. (2017). Effects of mobile devices on K-12 students' achievement: A meta-analysis: Effects of mobile devices. Journal of Computer Assisted Learning, 33(4), 355-369. https://doi.org/10.1111/jcal.12184

Vahtivuori-Hänninen, S., Kynäslahti, H., \& Kynäslahti, H. (2012). Icts in a school's everyday life. In H. Niemi, A. Toom, \& A. Kallioniemi (Eds.), Miracle of education (pp. 237-248). Rotterdam: SensePublishers. https://doi.org/10.1007/978-94-6091-811-7_16

Veerabhadram, P., de Beer, D., \& Conradie, P. (2012). A mobile design framework for continuous mobile learning environment in higher education. International Journal of Scientific and Engineering Research, 3(10), 1-9.

Voogt, J., Knezek, G., Cox, M., Knezek, D., \& ten Brummelhuis, A. (2013). Under which conditions does ICT have a positive effect on teaching and learning? A Call to Action. Journal of Computer Assisted Learning, 29(1), 4-14. https://doi.org/10.1111/j.1365-2729.2011.00453.x

Wiggins, S. (2016). Charting the future of SPN: The SPN strategic plan. Journal of Pediatric Nursing, 31(4), 459-462. https://doi.org/10.1016/j.pedn.2016.04.006

Williams, N. L., \& Larwin, K. H. (2016). One-to-one computing and student achievement in Ohio High Schools. Journal of Research on Technology in Education, 48(3), 143-158. https://doi.org/10.1080/ 15391523.2016.1175857

Wu, W.-H., Wu, Y.-C.J., Chen, C.-Y., Kao, H.-Y., Lin, C.-H., \& Huang, S.-H. (2012). Review of trends from mobile learning studies: A meta-analysis. Computers and Education, 59(2), 817-827. https://doi.org/ 10.1016/j.compedu.2012.03.016

Yousra Banoor, R., Mohammad Issack, S., \& Frank, R. (2019). The use of learning analytics to improve online learning outcomes: A systematic literature review. In Pan-commonwealth forum. http://oasis. col.org/handle/11599/3275.

Publisher's Note Springer Nature remains neutral with regard to jurisdictional claims in published maps and institutional affiliations. 